minated type of mineralisation and contain a rather high percentage of radioelements. Enrichments of allanite are most frequent in amphibolite facies environments, with low $\mathrm{Th}$. Uraninite mineralised rocks locally have a very high $U$ content, but they occur only in small isolated spots. Comparison between the radioactive mineral occurrences of the Nordre Strømfjord area shows a positive correlation between increasing metamorphic grade, thorium and the occurrence of monazite.

Vein type mineralisation is represented by uraniferous pyrochlore and Th-mineral enrichments in shear zones within the carbonatite complexes. By far the most interesting mineral occurrence is the vein type pyrochlore mineralisation in the Sarfartôq complex. This represents one of three pyrochlore phases related to the carbonatite activity, where $U$ and also $\mathrm{Nb}$ and REE are exceptionally concentrated due to very favourable depositional controls.

\title{
References
}

Boucot, A. J. 1949: Allanite from Godhaab, South Greenland. Rocks and Minerals 24, 35 and 61. Bøggild, O. B. 1953: The mineralogy of Greenland. Meddr Grønland 149(3), 1-442.

Gothenborg, J. \& Pedersen, J. L. 1975: Exploration of the Qaqarssuk carbonatite complex 1975, part II. Kryolitselskabet Øresund A/S, Unpublished company report.

Noe-Nygaard, A. 1958: En undersøgelse af prøver af allanit fra Grønland. Unpublished GGU report, $14 \mathrm{pp}$.

Secher, K. 1976: Airborne radiometric survey between $66^{\circ}$ and $69^{\circ} \mathrm{N}$, southern and central West Greenland. Rapp. Grønlands geol. Unders. 80, 65-67.

Secher, K. 1977: Airborne radiometric survey between $63^{\circ}$ and $66^{\circ} \mathrm{N}$, southern West Greenland. Rapp. Grønlands geol. Unders. 85, 49-50.

Secher, K. \& Larsen, L. M. (in press): Geology and mineralogy of the Sarfartôq carbonatite complex, southern West Greenland. Lithos.

Watt, M. 1977: Geokemisk prøveindsamling i Nordre Strømfjord og Sarfartôq, centrale Vestgrønland. Unpublished GGU report, 12 pp.

\section{Lamprophyric and kimberlitic dykes associated with the Sarfartôq carbonatite complex, southern West Greenland}

\section{Lotte Melchior Larsen}

Lamprophyric and kimberlitic dykes are known to be widely distributed in the Holsteinsborg - Søndre Strømfjord area. Escher \& Watterson (1973) published a map showing dyke concentrations in two areas, the coastal region between Holsteinsborg and Itivdleq, and an inland area between Søndre Strømfjord and Sukkertoppen Iskappe. In the latter area the 90 $\mathrm{km}^{2}$ Sarfartôq carbonatite complex was discovered in 1975 (Secher \& Larsen, 1978, and in press). During the 1979 field season in this area, numerous lamprophyric and kimberlitic 


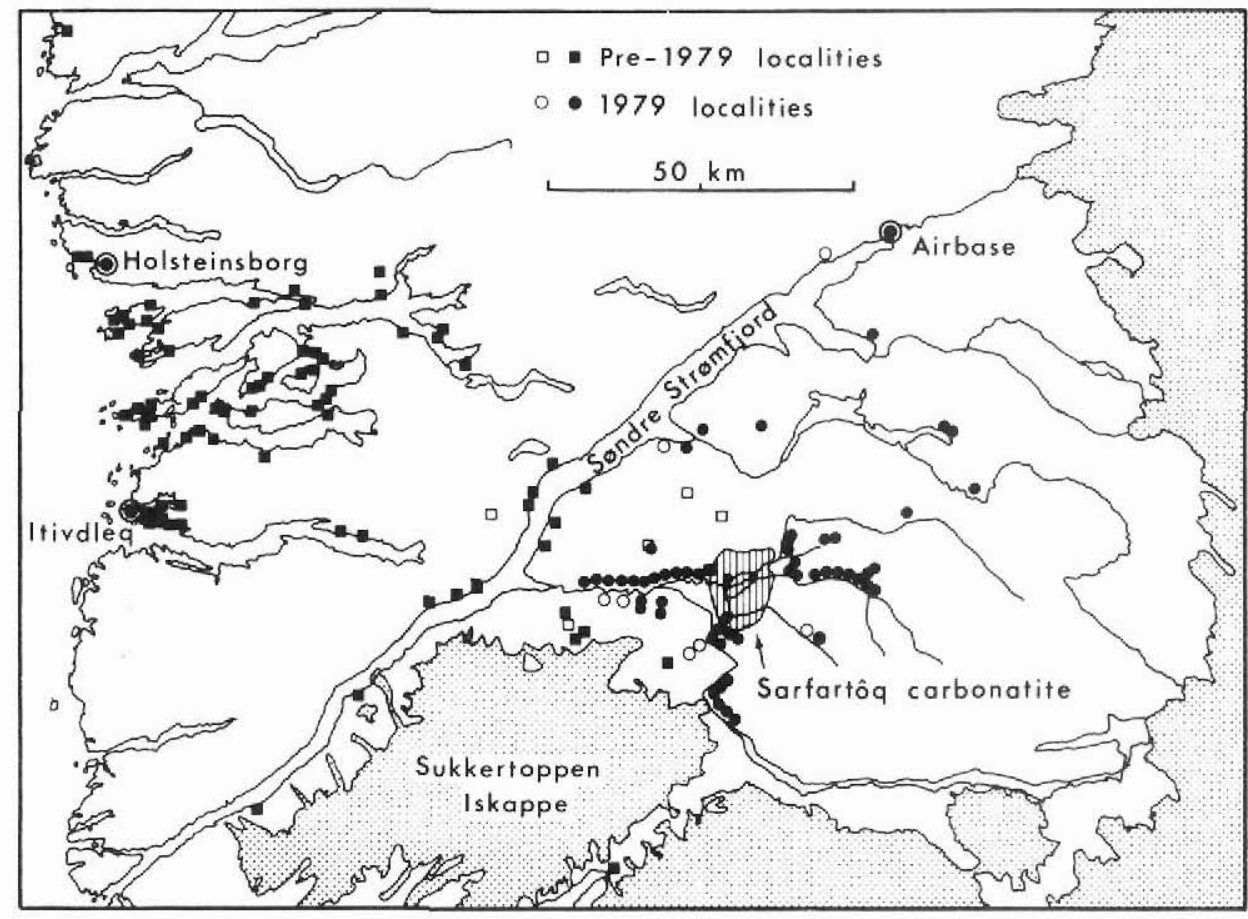

Fig. 20. Map showing the known localities of lamprophyric and kimberlitic dykes in the Holsteinsborg Søndre Strømfjord area. In the river valleys of the Sarfartôq region one dot usually represents several dykes. Data for the pre-1979 localities are from Noe-Nygaard \& Ramberg (1961), Escher \& Watterson (1973), Scott (1977), S. Bak Jensen and J. Korstgård (personal communications, 1979). Open symbols: Localities with loose blocks only.

dykes were found. Most of them are associated with the Sarfartôq carbonatite complex, and occur as extensive cone sheets centred on the carbonatite, dipping $30-50^{\circ}$ towards the centre.

\section{Distribution}

Fig. 20 shows the distribution of known dykes in the Holsteinsborg - Søndre Strømfjord area. There are sure to be many additions to this when the area has been studied in greater detail. The generally thin $(20-40 \mathrm{~cm})$ dykes are difficult to detect, because the rocks usually weather out and often leave no indication of their presence. Exposure of the dykes is strongly dependent on topography. They are most easily found in areas with pronounced differences in relief, particularly on steep valley sides exposed to the south or west with fresh scree fans. This is clearly seen in fig. 20. On the other hand there is very little chance of finding these dykes on plateaus and gently sloping valley sides. There is for instance no 
reason to suppose that the apparently low density of dykes north of the carbonatite complex (fig. 20) is correct - the relatively smooth topography in this area simply prevents the detection of any dykes.

\section{Petrography}

The dykes vary in thickness from a few centimetres to $1.5 \mathrm{~m}$. They are dark grey or brownish, with greyish-green weathering and granulated weathering surfaces. They often show signs of multiple intrusion, with internal contacts and grain-size variations. The outer chilled zones sometimes have very high carbonate contents and rusty weathering, in which case they are extremely similar to the carbonatite dykes of the Sarfartôq complex.

The dykes are nearly all olivine- and phlogopite-porphyritic. Other phenocryst/megacryst phases are opaque oxides, occasional clinopyroxene, and rare garnet. The matrix mainly consists of carbonate, with lesser amounts of serpentine, olivine, phlogopite, and opaque oxides. Occasional clinopyroxene, amphibole and perovskite, and rare apatite also occur. The petrographic variation ranges from olivine-poor types with orange reversely pleochroic phlogopite, rather similar to the carbonatite dykes in the Sarfartôq complex, through types rich in both olivine and light brown phlogopite phenocrysts, to very olivine-rich types in which nearly colourless phlogopite is very subordinate. Inclusions, mainly of dunite and peridotite, are confined to the more olivine-rich rocks where they are quite common. The petrographic variation thus indicates that representatives of a whole spectrum of carbonate-silicate magmas are present.

A number of dykes of an aberrant type have been found east of the Sarfartôq complex. These have megacrysts/phenocrysts of phlogopite, alkali feldspar, apatite, clinopyroxene and magnetite in a groundmass of phlogopite, green amphibole, apatite (abundant), alkali feldspar and carbonate.

The association of kimberlites sensu strictu with carbonatite complexes has recently been questioned by Mitchell (1979). Of the dykes around the Sarfartôq complex relatively few examples containing garnet nodules and garnet peridotite inclusions can be classified with certainty as kimberlite according to Mitchell's definition. For the majority of the dykes the term ultrabasic lamprophyre is more appropriate at this stage.

\section{Structure}

Within the carbonatite complex itself very few lamprohyric dykes have been found, and except for one these are all strongly altered, sheared and faulted, and must be earlier than most of the carbonatite activity.

Outside the complex, and within a distance of approximately $20 \mathrm{~km}$ from its margins, the majority of the dykes strike tangentially to the complex and dip $30-50^{\circ}$ towards the centre (fig. 21). In the same area the gneisses possess a pronounced joint system with the same orientation, and it is in this joint system that the lamprophyre and kimberlite dykes are situated. (Many joints are, of course, without dykes). The total volume of dykes in this area is of the order of one per mille of the basement. This gives a total surface outcrop of approximately $2 \mathrm{~km}^{2}$, compared to an estimated $6-7 \mathrm{~km}^{2}$ of carbonatite in the central complex.

The apatite-rich dykes occurring east of the carbonatite complex have steep dips $\left(60-90^{\circ}\right.$, 


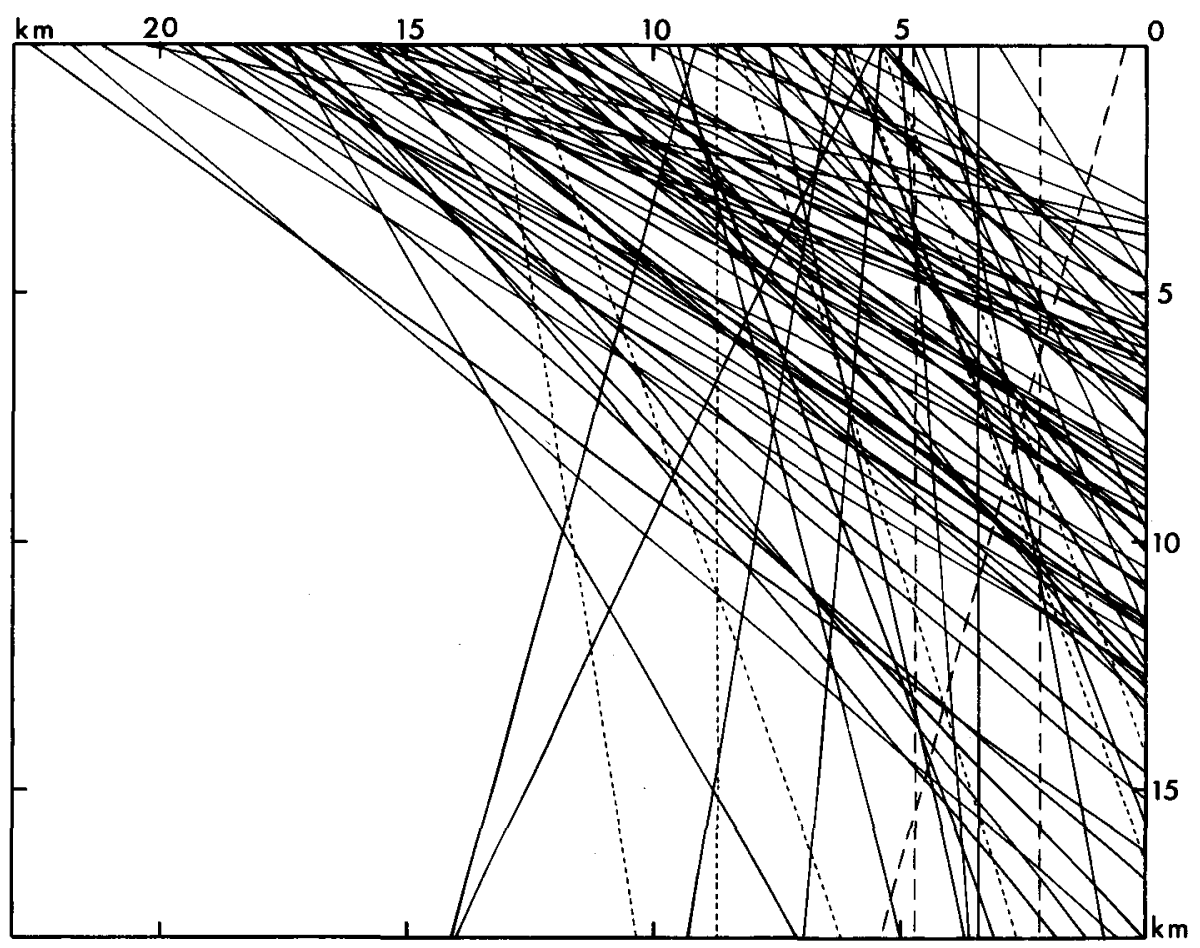

Fig. 21. Projection of the dykes on a vertical plane through the centre of the carbonatite complex. The centre is represented by the right edge of the figure, and the 'radius' of the complex itself is 4-6 km at the surface. Full lines: dykes occurring outside the complex. Dashed lines: dykes occurring inside the complex. Dotted lines: Apatite-rich dykes of aberrant type (see text).

fig. 21) and are often sheared and jointed, and in two instances cut by carbonatite dykes.

Beyond $20 \mathrm{~km}$ from the carbonatite complex the gneisses do not possess the above mentioned joint system. Dykes occur also in these areas, but their orientations are not obviously related to the complex. The number of dykes cannot be assessed due to the lack of exposure. However, they are probably very numerous in these areas too, because the dyke localities beyond $20 \mathrm{~km}$ from the carbonatite were all found by spot tests of sites with promising topography, and not one single site was tested with negative results. The limits of the distribution of these dykes have yet to be established.

\section{Relation to the Holsteinsborg-Itivdleq dykes}

The abundant dykes in the Sarfartôq region are obviously associated with the carbonatite complex and occur as cone sheets centred on it. Beyond $20 \mathrm{~km}$ from the complex, however, this relation is not certain, and the dykes may either belong to the carbonatite-associated swarm or to an eastern continuation of the Holsteinsborg-Itivdleq coastal zone with high dyke concentrations. It is very probable that this 'coastal dyke swarm' extends eastwards and 
that the distribution 'gap' in fig. 20 is spurious and due to the lack of coastal sections in that area. Several of the easternmost dykes localised in 1979 (fig. 20) indeed have the east-west strike directions characteristic of the coastal dykes (Escher \& Watterson, 1973; Scott, 1977; J. Korstgård, personal communication). The Sarfartôq cone sheet swarm may thus be interfering with a larger swarm of east-west trending dykes, possibly centred on the Ikertoq shear zone (Bak et al., 1975).

\title{
Acknowledgement
}

John Korstgård is thanked for information about several dyke localities included in fig. 20.

\section{References}

Bak, J., Sørensen, K., Grocott, J., Korstgård, J. A., Nash, D. \& Watterson, J. 1975: Tectonic implications of Precambrian shear belts in western Greenland. Nature Lond. 254, 566-569.

Escher, A. \& Watterson, J. 1973: Kimberlites and associated rocks in the Holsteinsborg - Søndre Strømfjord region, central West Greenland. Rapp. Grønlands geol. Unders. 55, $26-27$.

Mitchell, R. H. 1979: The alleged kimberlite-carbonatite relationship: additional contrary mineralogical evidence. Amer. J. Sci. 279, 570-589.

Noe-Nygaard, A. \& Ramberg, H. 1961: Geological reconnaissance map of the country between latitudes $69^{\circ} \mathrm{N}$ and $63^{\circ} 45^{\prime} \mathrm{N}$, West Greenland. Meddr Grønland 123(5), $9 \mathrm{pp}$.

Scott, B. H. 1977: Petrogenesis of kimberlites and associated potassic lamprophyres from central West Greenland. Unpubl. Ph.D. thesis, University of Edinburgh.

Secher, K. \& Larsen, L. M. 1978: A new Phanerozoic carbonatite complex in southern West Greenland. Rapp. Grønlands geol. Unders. 90, 46-50.

Secher, K. \& Larsen, L. M. in press: Geology and mineralogy of the Sarfartoq carbonatite complex, southern West Greenland. Lithos.

\section{An ultrabasic pipe in the eastern Sukkertoppen region, southern West Greenland}

\author{
R. P. Hall
}

An unusual occurrence of ultrabasic material was located in the eastern Sukkertoppen region during the reconnaissance mapping programme of 1977 , the findings of which were described by Allaart et al. (1978). It occurs on a small exposure on the west side of a north-pointing peninsula in the middle of the large nunatak Majorqap alángua $\left(65^{\circ} 53^{\prime} \mathrm{N}\right.$, $50^{\circ} 40^{\prime} \mathrm{W}$ ), to the north-east of the Majorqaq valley (Hall, 1978, fig. 21). The area is composed predominantly of a suite of granulite facies granitic gneisses which contain numerous enclaves of pyroxene-bearing amphibolites, and locally anorthositic and gabbroic rocks similar to those seen in the Fiskenæsset anorthosite complex (Myers, 1975). The 